\title{
Occurrence of Atypical and New Genotypes of Toxoplasma Gondii in Free-Range Chickens Intended for Human Consumption in Brazil
}

\author{
Ana Clécia dos Santos Silva ${ }^{1,2} \cdot$ Luiz Daniel de Barros ${ }^{1}\left[\right.$. Viviane Melo Coelho Barros ${ }^{2}$. \\ Adrianne Mota de Alcântara ${ }^{3}$. Müller Ribeiro Andrade ${ }^{3}$ - João Luis Garcia ${ }^{1} \cdot$ Rinaldo Aparecido Mota $^{3}$. \\ Wagnner José Nascimento Porto
}

Received: 30 July 2019 / Accepted: 20 February 2020 / Published online: 5 March 2020

(c) Witold Stefański Institute of Parasitology, Polish Academy of Sciences 2020

\begin{abstract}
Purpose The aim of the present study was to detect and genotype $T$. gondii in free-range chickens destined to human consumption in Alagoas state, Brazil.

Methods Two hundred blood samples were collected from free-range chickens and submitted to indirect immunofluorescence antibody test (IFAT). Brain tissue from 14 animals randomly selected were subjected to mouse bioassay. Positive samples in mouse bioassay were submitted to PCR and genotyped by PCR-RFLP.

Results Out of two hundred blood samples from chickens, 72 (36\%) samples were considered positive by IFAT. Two $T$. gondii strains were isolated, both being characterized as atypical and classified as \#146 and a new genotype, named \#279 in ToxoDB database.

Conclusions Our results showed a sero-occurrence of $T$. gondii in free-range chickens intended for humans, and the genetic diversity of the parasite in Brazil, with a new genotype described.
\end{abstract}

Keywords Toxoplasmosis $\cdot$ Genotyping $\cdot$ PCR-RFLP $\cdot$ Zoonosis

\section{Introduction}

Toxoplasma gondii is a protozoan parasite that can infect all warm-blooded animals and is widely prevalent in humans and animals worldwide; usually the infections is asymptomatic; however, congenital infection can cause damage to the fetus and reproductive disorders in humans and animals [1]. Humans mainly become infected by ingesting undercooked or raw meat contaminated with tissue cysts, or by

Luiz Daniel de Barros

daniel_vetuel@hotmail.com

1 Laboratory of Animal Protozoology, Department of Preventive Veterinary Medicine, Universidade Estadual de Londrina, Rodovia Celso Garcia Cid, Pr 445 km 380, Londrina, PR 86057-970, Brazil

2 Laboratory of Veterinary Parasitology, Universidade Federal de Alagoas, Fazenda São Luis, s/n, Viçosa, AL 57700-970, Brazil

3 Laboratory of Infectious Diseases of Domestic Animals, Universidade Federal Rural de Pernambuco, Rua Dom Manoel de Medeiros, s/n Dois Irmãos, Recife, PE 52171-900, Brazil ingesting food or water contaminated with $T$. gondii oocysts [2].

Due to their feeding habits, free-range chickens are considered good indicator of soil contamination by $T$. gondii oocysts and an important source of infection for humans, being used as sentinel animals in regions with high prevalence of human infection [3].

Nowadays, there is a higher demand by consumers for differentiated products with superior quality, which has been influencing changes in the animal production systems. Although there is an increase in production systems handling with animal welfare, extensive system may present risks if it is not well managed, as the animals are reared loosely and may have more contact with potential pathogenic agents such as T. gondii [4].

In the past, $T$. gondii population structure was considered clonal, being T. gondii strains classified as Types I, II or III based on SAG2 marker [5]. However, after developing of other molecular markers, studies from different regions of the world, especially in Central and South America, have shown that $T$. gondii has a high genetic diversity, with high prevalence of atypical strains [6, 7]. In mice, the 
clonal genotypes type I are classified as high virulence $\left(\mathrm{LD}_{100}=1\right)$, while types II and III are classified as medium to low virulence $\left(\mathrm{LD}_{100} \geq 10^{3}\right)$ [5]; however, atypical genotypes are highly virulent to mice, with correlation of ROP18 and ROP5 alleles with virulence [8]. In humans, atypical genotypes have been reported as cause of congenital ocular toxoplasmosis and acute systemic toxoplasmosis in immunocompetent individuals, showing a potential association between the atypical genotype and pathogenicity in human hosts [8-10].

The aim of the present study was to evaluate the occurrence of anti-T. gondii antibodies and genetically characterize isolates obtained from free-range chickens from Brazil.

\section{Material and Methods}

\section{Animals and Study Area}

Two hundred free-ranging chickens (Gallus gallus domesticus) from seven different farms belonging to municipality of Viçosa, state of Alagoas, northeast Brazil, had their blood taken, between February and July 2016. Blood samples were collected by puncture of the brachial vein and serum samples obtained were stored at $-20^{\circ} \mathrm{C}$ until further analysis. Fourteen chickens from all seven farms were randomly selected and had their brain tissue collected aseptically, followed by mouse bioassay (Table 1). All procedures involving animals were conducted in accordance with good animal practices and approved by Animal Ethics Committee (number 43/2015).

\section{Serology}

Serum samples obtained from chickens and mice from mouse bioassay were subjected to immunofluorescence antibody test (IFAT) according to methodology previously described [11]. Tachyzoites of RH strain were used as

Table 1 Blood and brain samples collection from free-range chickens (Gallus gallus domesticus) intended for human consumption in Brazil according to each farm

\begin{tabular}{lll}
\hline Farms & Blood samples & Brain samples \\
\hline A & 10 & 1 \\
B & 10 & 1 \\
C & 5 & 1 \\
D & 38 & 2 \\
E & 43 & 4 \\
F & 51 & 3 \\
G & 43 & 2 \\
Total & 200 & 14 \\
\hline
\end{tabular}

antigen, and serum samples from chickens known as positive and negative for $T$. gondii were used as controls and included in all slides. Only serum samples that showed fluorescence over the whole parasites' surface were considered positive. Samples with titers with $\geq 16$, for both chickens and mice, were considered positive.

\section{Mouse Bioassay}

Mouse bioassay was performed according to methodology previously described [12]. Brain tissue (30 g) from each animal was macerated, homogenized with $0.85 \% \mathrm{NaCl}$ solution (saline) 1:5 (w/v), filtered through gauze and centrifuged at $700 \times g$ for $10 \mathrm{~min}$. The supernatant was discarded, the pellet resuspended with $50 \mathrm{ml}$ of saline solution and centrifuged again. Next, the supernatant was discarded, the pellet resuspended in $2 \mathrm{ml}$ of antibiotic saline solution (1000 IU of penicillin and $100 \mu \mathrm{g}$ of streptomycin per $\mathrm{ml}$ ) and inoculated intraperitoneally into two Swiss Webster (SW) mice. Mice were observed daily and those that showed clinical signs of infection were euthanized for collection of peritoneal liquid for detection of tachyzoites. Mice who survived for 45 days after inoculation were euthanized and blood and brain tissue samples were taken for antibodies and tissue cyst detection, respectively. Positive samples for presence of $T$. gondii were inoculated in MARC-145 cells for growth of the parasite [13].

\section{DNA Extraction and PCR}

DNA extraction was performed using a commercial kit (DNeasy Blood and Tissues Kit, Qiagen ${ }^{\circledR}$, Germany) following the manufacturer's instructions. T. gondii DNA was detected by a nested PCR, using the external primers TgNNTgNN2 and internal primers TgNP1-TgNP2, amplifying a fragment of $227 \mathrm{bp}$ of the ITS1 region of the parasite [14]. DNA of RH strain tachyzoites and ultrapure water were used as positive and negative controls, respectively, and included in all PCR run. PCR products were subjected to electrophoresis on 1.5\% agarose gel stained with Sybr Safe DNA Gel Stain (Invitrogen ${ }^{\circledR}$, USA), and visualized and photographed under UV light.

\section{Multilocus PCRP-RFLP}

Genetic characterization of the isolates was performed by polymerase chain reaction-restriction fragment length polymorphism using 11 genetic markers (SAG1, SAG2, alt. SAG2, SAG3, BTUB, GRA6, c22-8, c29-2, L358, PK1 and Apico) as previously described [7]. All products were subjected to electrophoresis on 3\% agarose gel stained with Sybr Safe DNA Gel Stain (Invitrogen ${ }^{\circledR}$, USA), visualized and photographed under UV light. The results obtained were 
compared and classified according to the genotypes present in ToxoDB in (https://toxodb.org/toxo/). Phylogenetic tree comparing the isolates with the reference strains was constructed using the Split Tree software version 4.13 [15].

\section{Results and Discussion}

Antibodies against T. gondii were observed in $36 \%$ (72/200) according with IFAT. Animals presented titers of 16 (8.22\%), 32 (10.96\%) 64 (17.8\%), 128 (13.69\%), 256 $(19.17 \%)$ and $512(30.14 \%)$. Previous studies performed in free-range chickens in different regions from Brazil have shown a prevalence ranging from 10 to $100 \%[16,17]$. In the northeast region of Brazil, studies conducted with backyard chickens have described a prevalence of T. gondii up $40.56 \%$ by means the IFAT, and $94.8 \%$ of studied farm with at least one positive animal $[18,19]$, similar to our results, where $36 \%$ of animals and $100 \%$ of farms were considered positive.

In the mouse bioassay, $T$. gondii was isolated from two seropositive chickens, with titers of 16 and 64 . The obtained isolates, named as TgCkAL01 and TgCkAL02, were obtained from tissue cyst of euthanized mice. One mouse developed clinical signs of chronic infection at 37 days postinoculation, being euthanized for collection of peritoneal liquid and brain tissue. These biological samples were inoculated in MARC-145 cells for parasite growth; however, only in the cell culture inoculated with brain tissue was observed parasites. According with genetic characterization, two atypical genotypes were observed: one matched with ToxoDB genotype \#146 and the other one has not been described before (classified now as ToxoDB \#279) (Table 2).

In our study, we had an isolation rate of $14.3 \%$, with two isolates obtained. Previous studies with free-range chickens form Brazil have described an isolation ranging from 15.12 to $87.87 \%$ [20-22]. In the present study, isolates was obtained from seropositive animals; however, previous studies have described isolation of the parasite from seronegative animals, including chickens and doves $[23,24]$. In the past, $T$. gondii was considered to be parasite with low degree of genetic diversity [5] with three clonal lineages; however, studies performed later, mainly in South American countries, a higher genetic diversity was observed, with occurrence of many atypical genotypes [6]. The isolates obtained in our study were considered of low to moderate pathogenicity, since no animal showed clinical signs of acute infection; however, since in the mouse bioassay the infectious dose is unknown, additional studies aiming to determine the virulence patterns of these isolates should be performed [25].

Genotype \#146 has already been described only in chickens, cattle egret (Bubulcus ibis) and feral cats (Felis catus) [1, 26, 27], all of them being obtained of animals from Fernando de Noronha Island, in Brazil. Since Viçosa and Fernando de Noronha Island are apart by more than $800 \mathrm{~km}$, we can observe that $T$. gondii genotypes are spread over the country. Besides the isolate \#146, we detected a new genotype, now classified as \#279, showing a high genetic diversity of $T$. gondii in Brazil, as previously observed in different isolates from Brazilian animals $[23,28]$. The phylogenetic tree (Fig. 1 shows that the genotypes observed in the present study are not related with any clonal strains, being more related with Brazilian typical strains BrII and BrIII, which have been isolated in different animals in Brazil; these strains have also shown similar patterns of pathogenicity with our isolates, since BrII, and BrIII are considered as intermediate and nonvirulent strains, respectively [29].

Table 2 PCR-RFLP genotypic profiles from Toxoplasma gondii isolates obtained from free-range chickens (Gallus gallus domesticus) intended for human consumption in Brazil

\begin{tabular}{|c|c|c|c|c|c|c|c|c|c|c|c|c|c|}
\hline \multirow[t]{2}{*}{ Strain ID } & \multicolumn{12}{|c|}{ Genetic markers } & \multirow[t]{2}{*}{ References } \\
\hline & SAG1 & $5^{\prime}-3^{\prime}$ SAG2 & alt. SAG2 & SAG3 & BTUB & GRA6 & C22-8 & C29-2 & L358 & PK1 & Apico & ToxoDB & \\
\hline GT1 & I & I & I & I & I & I & I & I & I & I & I & $\# 10$ & [30] \\
\hline PTG & II or III & II & II & II & II & II & II & II & II & II & II & $\# 1$ & [30] \\
\hline CTG & II or III & III & III & III & III & III & III & III & III & III & III & \#2 & [30] \\
\hline MAS & $\mathrm{u}-1$ & I & II & III & III & III & $\mathrm{u}-\mathrm{l}$ & I & I & III & I & \#17 & [30] \\
\hline $\mathrm{TgCgCal}$ & I & II & II & III & II & II & II & $\mathrm{u}-\mathrm{l}$ & I & $\mathrm{u}-2$ & I & \#66 & [31] \\
\hline $\mathrm{TgCtBr} 5$ & I & III & III & III & III & III & I & I & I & $\mathrm{u}-1$ & I & \#19 & [29] \\
\hline TgCtBr64 & I & I & $\mathrm{u}-1$ & III & III & III & $\mathrm{u}-1$ & I & III & III & I & $\# 111$ & [29] \\
\hline TgRsCrl & $\mathrm{u}-1$ & I & II & III & I & III & $\mathrm{u}-2$ & I & I & III & I & $\# 52$ & [32] \\
\hline \multicolumn{14}{|c|}{ Present study } \\
\hline TgCkAl01 & I & I & I & III & II & II & I & III & III & II & III & \#146 & \\
\hline TgCkAl02 & I & III & III & I & III & III & II & III & III & I & III & New (\#279) & \\
\hline
\end{tabular}


Fig. 1 Phylogenetic tree of Toxoplasma gondii isolates obtained from free-range chickens (Gallus gallus domesticus) intended for human consumption in Brazil. Reference strains are marked in green, Brazilian typical strains (BrI, BrII, BrIII and BrIV) in black and genotypes observed in our study in red (color figure online)

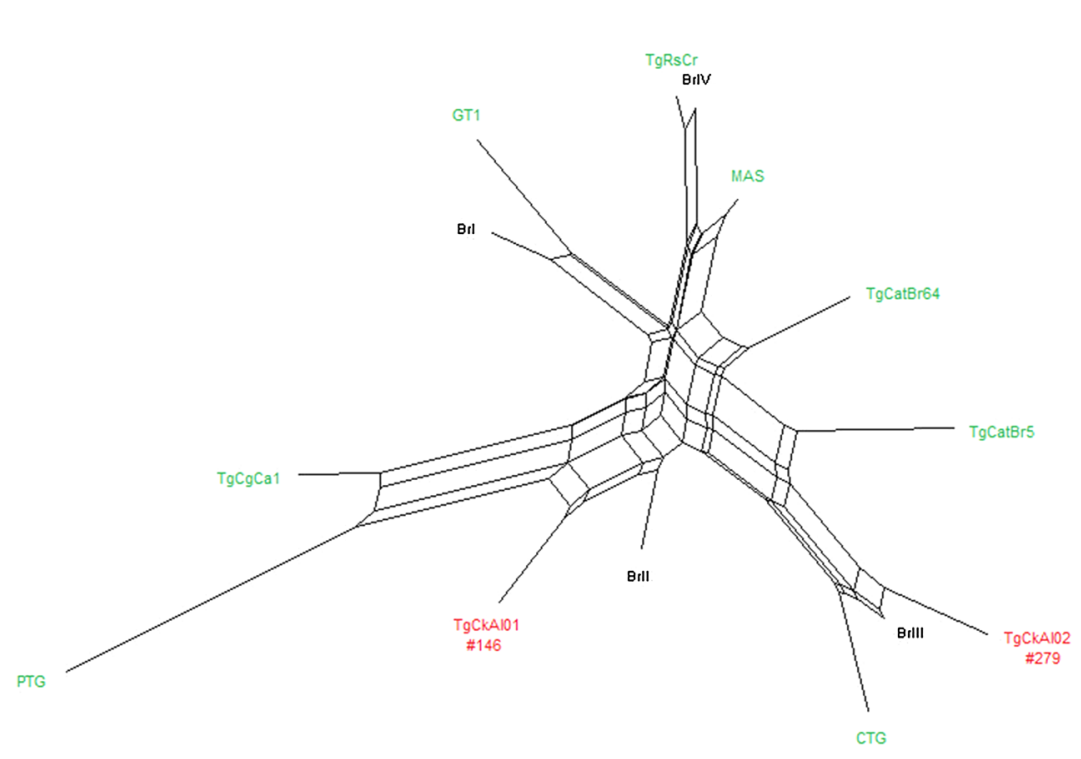

\section{Conclusion}

The presence of anti $-T$. gondii antibodies and the presence of viable parasite in chicken tissues indicate the existence of environmental contamination in the region and demonstrate the circulation of new genotypes of the parasite. Further studies evaluating the pathogenic patterns of these isolates should be done to improve the understanding of the epidemiology and potential association with human toxoplasmosis in this region.

Acknowledgements We would like to thank the Conselho Nacional de Desenvolvimento Científico e Tecnológico (CNPq) for financial support.

\section{Compliance with Ethical Standards}

Conflict of Interest On behalf of all authors, the corresponding author states that there is no conflict of interest.

Ethical Approval All procedures performed in studies involving animals were in accordance with ethical standards of the Animal Ethics Committee at which the studies were conducted (protocol number 43/2015).

\section{References}

1. Dubey JP, Rajendran C, Costa DGC et al (2010) New Toxoplasma gondii genotypes isolated from free-range chickens from the Fernando de Noronha, Brazil: unexpected findings. J Parasitol 96:709-712. https://doi.org/10.1645/GE-2425.1

2. Dubey JP, Jones JL (2008) Toxoplasma gondii infection in humans and animals in the United States. Int J Parasitol 38:1257-1278. https://doi.org/10.1016/j.ijpara.2008.03.007
3. Pena HFJ, Soares RM, Amaku M et al (2006) Toxoplasma gondii infection in cats from São Paulo state, Brazil: Seroprevalence, oocyst shedding, isolation in mice, and biologic and molecular characterization. Res Vet Sci 81:58-67. https://doi.org/10.1016/j. rvsc.2005.09.007

4. Djokic V, Blaga R, Aubert D et al (2016) Toxoplasma gondii infection in pork produced in France. Parasitology 143:557-567. https://doi.org/10.1017/S0031182015001870

5. Howe DK, Sibley LD (1995) Toxoplasma gondii comprises three clonal lineages: correlation of parasite genotype with human disease. J Infect Dis 172:1561-1566. https://doi.org/10.1093/infdi s/172.6.1561

6. Shwab EK, Zhu XQ, Majumdar D et al (2014) Geographical patterns of Toxoplasma gondii genetic diversity revealed by multilocus PCR-RFLP genotyping. Parasitology 141:453-461. https:// doi.org/10.1017/S0031182013001844

7. Su C, Shwab EK, Zhou P et al (2010) Moving towards an integrated approach to molecular detection and identification of Toxoplasma gondii. Parasitology 137:1-11. https://doi.org/10.1017/ S0031182009991065

8. Shwab EK, Jiang T, Pena HFJ et al (2016) The ROP18 and ROP5 gene allele types are highly predictive of virulence in mice across globally distributed strains of Toxoplasma gondii. Int J Parasitol. https://doi.org/10.1016/j.ijpara.2015.10.005

9. Carme B, Bissuel F, Ajzenberg D et al (2002) Severe acquired toxoplasmosis in immunocompetent adult patients in French Guiana. J Clin Microbiol 40:4037-4044. https://doi.org/10.1128/ JCM.40.11.4037-4044.2002

10. Grigg ME, Dubey JP, Nussenblatt RB (2015) Ocular toxoplasmosis: lessons from Brazil. Am J Ophthalmol 159:999-1001. https:// doi.org/10.1016/j.ajo.2015.04.005

11. Camargo M (1973) Introdução às técnicas de imunofluorescência. Rev Bras Patol Clin 10:143-171. https://doi.org/10.1136/ jnnp.2005.075242

12. Dubey JP (1998) Refinement of pepsin digestion method for isolation of Toxoplasma gondii from infected tissues. Vet Parasitol 74:75-77. https://doi.org/10.1016/S0304-4017(97)00135-0

13. Brom PRF, Regidor-Cerrillo J, Collantes-Fernández E et al (2014) Genetic characterisation of Neospora caninum strains from clinical samples of zebuine foetuses obtained in abattoirs in Goiás, 
Brazil. Vet Parasitol 204:381-387. https://doi.org/10.1016/j.vetpa r.2014.05.011

14. Hurtado A, Aduriz G, Moreno B et al (2001) Single tube nested PCR for the detection of Toxoplasma gondii in fetal tissues from naturally aborted ewes. Vet Parasitol 102:17-27. https://doi. org/10.1016/S0304-4017(01)00526-X

15. Huson DH, Bryant D (2006) Application of phylogenetic networks in evolutionary studies. Mol Biol Evol 23:254-267. https://doi. org $/ 10.1093 / \mathrm{molbev} / \mathrm{msj030}$

16. de Oliveira LN, Costa Junior LM, de Melo CF et al (2009) Toxoplasma gondii isolates from free-range chickens from the northeast region of Brazil. J Parasitol 95:235-237. https://doi. org/10.1645/GE-1730.1

17. Garcia JL, Navarro IT, Ogawa L, Marana ERM (2000) Soroprevalência do Toxoplasma gondii em galinhas (Gallus gallus domesticus) de criações domésticas, oriundas de propriedades rurais do Norte do Paraná, Brasil. Ciência Rural 30:123-127. https ://doi.org/10.1590/S0103-84782000000100020

18. Fernandes MFTS, Cavalcanti EFTSF, da Silva JG et al (2016) Occurrence of anti-Toxoplasma gondii antibodies and parasite DNA in backyard chicken breeding in Northeast, Brazil. Rev Bras Parasitol Vet 25:105-108. https://doi.org/10.1590/S1984-29612 016012

19. de Sá SG, Ribeiro-Andrade M, Silva LTR et al (2017) Risk factors associated with Toxoplasma gondii infection in free-range chickens in the semiarid region of Brazil. Rev Bras Parasitol Vet 26:221-225. https://doi.org/10.1590/s1984-29612017033

20. Feitosa TF, Vilela VLR, de Almeida-Neto JL et al (2017) First report of typical Brazilian Toxoplasma gondii genotypes from isolates of free-range chickens (Gallus gallus domesticus) circulating in the state of Paraíba, Northeast Brazil. Parasitol Res 116:2265-2270. https://doi.org/10.1007/s00436-017-5531-x

21. Pena HFJ, Alves BF, Soares HS et al (2018) Free-range chickens from Santa Catarina state, southern Brazil, as asymptomatic intermediate hosts for Toxoplasma gondii clonal type I and typical Brazilian genotypes. Vet Parasitol Reg Stud Rep 13:55-59. https ://doi.org/10.1016/j.vprsr.2018.04.001

22. Trevisani N, Barros LD, Vieira-Neto A et al (2017) Genotyping of Toxoplasma gondii isolates from naturally infected Gallus domesticus in Santa Catarina state, Brazil. Arq Bras Med Veterinária e Zootec 69:139-145. https://doi.org/10.1590/1678-4162-8594

23. de Barros LD, Taroda A, Zulpo DL et al (2014) Genetic characterization of Toxoplasma gondii isolates from eared doves (Zenaida auriculata) in Brazil. Rev Bras Parasitol Vet 23:443-448. https:// doi.org/10.1590/S1984-29612014073
24. Vieira FEG, Sasse JP, Minutti AF et al (2018) Toxoplasma gondii: prevalence and characterization of new genotypes in free-range chickens from south Brazil. Parasitol Res. https://doi.org/10.1007/ s00436-017-5730-5

25. Saraf P, Shwab EK, Dubey JP, Su C (2017) On the determination of Toxoplasma gondii virulence in mice. Exp Parasitol 174:25-30. https://doi.org/10.1016/j.exppara.2017.01.009

26. Melo RPB, Almeida JC, Lima DCV et al (2016) Atypical Toxoplasma gondii genotype in feral cats from the Fernando de Noronha Island, northeastern Brazil. Vet Parasitol 224:92-95. https://doi.org/10.1016/J.VETPAR.2016.05.023

27. Vitaliano SN, Soares HS, Minervinoa HH et al (2014) Genetic characterization of Toxoplasma gondii from Brazilian wildlife revealed abundant new genotypes. Int J Parasitol Parasit Wildl 3:276-283. https://doi.org/10.1016/j.ijppaw.2014.09.003

28. Ragozo AMA, Pena HFJ, Yai LEO et al (2010) Genetic diversity among Toxoplasma gondii isolates of small ruminants from Brazil: novel genotypes revealed. Vet Parasitol 170:307-312. https:// doi.org/10.1016/j.vetpar.2010.02.024

29. Pena HFJ, Gennari SM, Dubey JP, Su C (2008) Population structure and mouse-virulence of Toxoplasma gondii in Brazil. Int $\mathrm{J}$ Parasitol 38:561-569. https://doi.org/10.1016/j.ijpara.2007.09.004

30. Su C, Zhang X, Dubey JP (2006) Genotyping of Toxoplasma gondii by multilocus PCR-RFLP markers: a high resolution and simple method for identification of parasites. Int J Parasitol 36:841-848. https://doi.org/10.1016/j.ijpara.2006.03.003

31. Dubey JP, Quirk T, Pittt JA et al (2008) Isolation and genetic characterization of Toxoplasma gondii from raccoons (Procyon lotor), cats (Felis domesticus), striped skunk (Mephitis mephitis), black bear (Ursus americanus), and cougar (Puma concolor) from Canada. J Parasitol 94(1):42-45. https://doi.org/10.1645/ GE-1349.1

32. Dubey JP, Velmurugan GV, Morales JA et al (2009) Isolation of Toxoplasma gondii from the keel-billed toucan (Ramphastos sulfuratus) from Costa Rica. J Parasitol 95(2):467-468. https:// doi.org/10.1645/GE-1846.1

Publisher's Note Springer Nature remains neutral with regard to jurisdictional claims in published maps and institutional affiliations. 